\title{
Angiogenesis activity of Jatropha curcas L. latex in cream formulation on wound healing in mice
}

\author{
Ummu Balqis ${ }^{1}$, Darmawi ${ }^{2,3}$, Cut Dahlia Iskandar ${ }^{4}$ and Muhammad Nur Salim ${ }^{1,5}$
}

1. Laboratory of Pathology, Faculty of Veterinary Medicine, Syiah Kuala University, Banda Aceh 23111, Indonesia; 2. Laboratory of Microbiology, Faculty of Veterinary Medicine, Syiah Kuala University, Banda Aceh 23111, Indonesia; 3. Laboratory of Research, Faculty of Veterinary Medicine, Syiah Kuala University, Darussalam, Banda Aceh 23111, Indonesia; 4. Laboratory of Histology, Faculty of Veterinary Medicine, Syiah Kuala University, Banda Aceh 23111, Indonesia; 5. Study Program of Mathematics and Applied Sciences, Syiah Kuala University, Banda Aceh 23111, Indonesia.

Corresponding author: Muhammad Nur Salim, e-mail: mnursalim@unsyiah.ac.id

Co-authors: UB: ummu.balqis@unsyiah.ac.id, Darmawi: darmawi@unsyiah.ac.id, CDI: acut.ifan@gmail.com Received: 26-02-2018, Accepted: 05-06-2018, Published online: 15-07-2018

doi: 10.14202/vetworld.2018.939-943 How to cite this article: Balqis U, Darmawi, Iskandar CD, Salim MN (2018) Angiogenesis activity of Jatropha curcas L. latex in cream formulation on wound healing in mice, Veterinary World, 11(7): 939-943

\begin{abstract}
Aim: The aim of this research was to determine the angiogenesis activity of Jatropha curcas latex in cream formulation on CD34 immune expression during wound healing phase in mice skin.

Materials and Methods: Amount of 36 2-month-old male mice were used between 30 and 40 g. To surgical procedures, wound skin incision was performed $2.0 \mathrm{~cm}$ in length until subcutaneous on the paravertebral of each animal. The treatment was carried under locally anesthetized with procaine cream. All mice were divided into four groups, namely the base cream as control group (A), sulfadiazine $0.1 \%$ cream (B), Jatropha curcas latex cream $10 \%$ (C), and J. curcas latex cream $15 \%$ (D). All groups were treated entire surface of wound. All experiments were performed twice a day for 10 days. Experiments were terminated on days 3, 7, and 10, respectively. The wound healing was assayed in stained histological section in immunohistochemical of the wounds. The CD34 expression was investigated under a microscope.
\end{abstract}

Results: The results showed that the cream from $10 \%$ and $15 \%$ latex $J$. curcas revealed moderate immune reaction to CD34 on days 3 and 7 in wound healing of mice skin.

Conclusion: We concluded that the cream from $10 \%$ and $15 \%$ latex $J$. curcas has potential as angiogenesis activity in wound healing of mice skin.

Keywords: angiogenesis, CD34, Jatropha curcas latex cream, wound healing.

\section{Introduction}

The wound is defined as a raw skin surface and lost its surface epithelial coverage caused by various types of injuries or diseases [1,2]. It can be damaged or disruption to the normal anatomical structure and function of skin [3]. Wounds that exhibit impaired healing, including delayed acute wounds and chronic wounds, generally have failed to progress through the normal stages of healing [4]. Neovascularization or angiogenesis is important for wound healing process. Angiogenesis plays a role in wound healing by forming new blood vessels from preexisting vessels by invading the wound clot and organizing into a microvascular network throughout the granulation tissue [5]. However, angiogenesis also plays a role in the provision of nutrients and oxygen to the wound area and increases the formation of granulation tissue with its collagen and connective tissue proteins

Copyright: Balqis, et al. Open Access. This article is distributed under the terms of the Creative Commons Attribution 4.0 International License (http://creativecommons.org/licenses/by/4.0/), which permits unrestricted use, distribution, and reproduction in any medium, provided you give appropriate credit to the original author(s) and the source, provide a link to the Creative Commons license, and indicate if changes were made. The Creative Commons Public Domain Dedication waiver (http://creativecommons.org/ publicdomain/zero/1.0/) applies to the data made available in this article, unless otherwise stated. deposition [6]. A subpopulation of hematopoietic progenitor CD34 cells could directly contribute to the neovascularization and wound repair process [7]. CD34 is a cell surface marker that is expressed by a broad range of cells including hematopoietic, stromal, epithelial, and endothelial cells $[8,9]$.

Wound healing is influenced by many factors including the type of medication used. One is the use of traditional medicine. The use of traditional medicine is increasingly favored because of fewer side effects such as drugs from chemicals [10], the cost is relatively low, and it is easily accessible [11]. Secondary metabolites from herbal plants that are potential as microbial agents may help overcome the problem of antibiotic resistance [12]. Jatropha curcas L. (Euphorbiaceae) is multiple purpose with potential for biodiesel production and medicinal uses [13]. Some of the benefits of $J$. curcas are that they can adapt well to dry land, are easy to cultivate, and their utilization does not compete with food crops such as cassava, maize, coconut, and palm oil [14]. J. curcas is generally grown as a live fence for protection of agricultural fields from damage by livestock as it is not eaten by cattle [15] and to prevent erosion [16].

All parts of $J$. curcas have also been used in traditional medicine and for veterinary purposes [17]. 
The leaves and latex are used in healing of wounds, refractory ulcers, and septic gums, and styptic in cuts and bruises [18]. J. curcas contains a number of bioactive compounds that are flavonoids, saponins, tannins, and polivenol. The compounds play a role in antibacterial [19], antioxidant, anti-inflammatory, anticancer [20], antidiabetic activities [21], and wound healing [22]. However, limited information is available on the wound healing process of this plant, especially angiogenesis activity.

The aim of this research was to determine the angiogenesis activity of $J$. curcas latex in cream formulation on CD34 immune expression during wound healing phase in mice skin. The results will then be compared to that of treatment with sulfadiazine in standard wound therapy.

\section{Materials and Methods \\ Ethical approval}

This research was performed appropriately following the regulation of Animal Ethics Committee. This research was approved by the Animal Ethics Committee of Faculty of Veterinary Medicine, Syiah Kuala University, Banda Aceh, Indonesia (Approval No. 004/KEPH-C/VII/2017).

\section{Mice}

Amount of 36 heads male mice (Mus musculus) aged 2 months old and weighing 30-40 g were used in this study. All mice maintained individually in cages at the Laboratory of Pathology, Faculty of Veterinary Medicine, Syiah Kuala University. Feed and water were given ad libitum for 2 weeks.

\section{Preparation of $\mathrm{o} / \mathrm{w}$ cream formulation}

The latex used in the present study acquired a break of $J$. curcas leaf stems which were procured from a local farm around yard areas of Banda Aceh. The latex was collected in the morning with a break of leaf stems, latex at capacity into a sterile bottle. The latex was formulated in cream following the procedure as described by Muntiaha et al. [23]. J. curcas latex cream made with a base of oil in water $(\mathrm{O} / \mathrm{W})$ because the formulation is homogeneity, spreadability, simply to use, non-sticky, soothing on the skin, and easy to clean. A cream base was added little by little with the $10 \%$ and $15 \%$ latex of $J$. curcas in a porcelain dish containing $100 \mathrm{~g}$ of cream and stirred until homogeneous at room temperature. The dosages of $10 \%$ and $15 \%$ latex of $J$. curcas have been proven to be effective to use for topical for topical wound healing [24].

\section{Formation of excision wound model}

The mice skin wound was done by mean of surgical procedures as explained by Salim et al. [24]. Mice were locally anesthetized by topical cream with containing lidocaine $25 \mathrm{mg}$ and prilocaine $25 \mathrm{mg}$. Longitudinal wounds of about $2.0 \mathrm{~cm}$ were made on the paravertebral region till to subcutaneous under the aseptic condition and were observed throughout the experimental study.

\section{Grouping of mice for experimental design}

The mice were separated into four groups contained nine mice of each. group A as a negative control, the mice skin wound received base cream. group B as a positive control, the mice skin wound received standard drug containing sulfadiazine $0.1 \%$ cream. group $\mathrm{C}$, the mice skin wound treated with a cream containing $J$. curcas latex $10 \%$. group D the mice skin wound treated with a cream containing $J$. curcas latex $15 \%$. The topical experimentally applied twice daily at 08.00 am and $18.00 \mathrm{pm}$ starting from the day of wounding till to measure on $3^{\text {rd }}, 7^{\text {th }}$, and $10^{\text {th }}$ post-wounding day.

\section{Histopathological and immunohistochemical expres- sion of CD34}

Wound skin tissue samples were collected in $10 \%$ buffered formalin for histopathological examination $[25,26]$. The tissues were processed by routine paraffin embedding technique, and $5 \mu \mathrm{m}$ section was stained with immunohistochemical staining by standard methods as described by Darmawi et al. [27], using streptavidin-biotin complex. For angiogenesis immunoreaction, we used the CD34 monoclonal mouse antibody (Dako, 1:50 dilution) diluted in 1\% BSA in PBS. We defined the scores of CD34 expression as negative, 0 points (Grade 0 ), mild 1 point (Grade 1), moderate 2 points (Grade 2), and severe 3 points (Grade 3) [28]. The intensity of staining was recorded as weak, moderate, and strong [29].

\section{Results}

The results of the present study showed that immunohistochemical of CD34-positive expression is characterized by brown color on microscopic slides. The CD34 monoclonal mouse antibody had a strong reaction with antigen on the endothelial progenitor cells and endothelial cells as shown in Figures-1-3. On day 3, the CD34 positive cells were seen in endothelial cells of each group. The minimal immunoreactivity of CD34 positive cells was observed on group A (Grade 1). Meanwhile, the moderate immunoreactivity

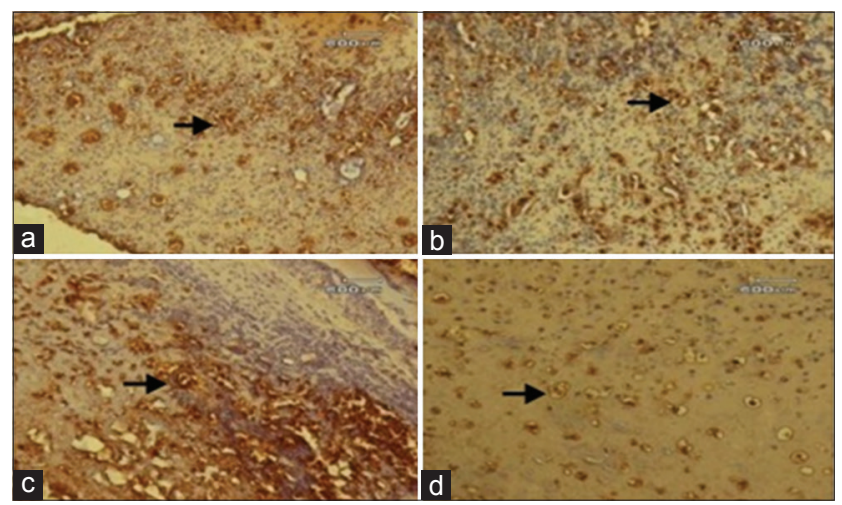

Figure-1: Photomicrograph of wounds skin on day 3 of treatment (streptavidin-biotin 40x). CD34-positive cells in endothelial cells each group that marked the brown color (arrow). (a) Minimal immunoreactivity CD34-positive cells on Group A (Grade 1). (b-d) Moderate immunoreactivity CD34-positive cells on Groups B, C, and D (Grade 2). 


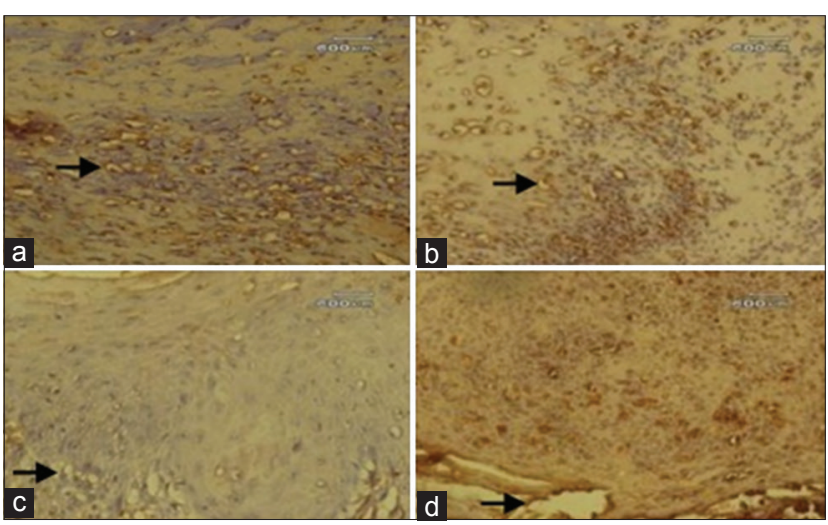

Figure-2: Photomicrograph of wounds skin on day 7 of treatment (streptavidin-biotin 40x). CD34-positive cells in endothelial cells each group that marked the brown color (arrow). (a) Minimal immunoreactivity CD34-positive cells on Group A (Grade 1). (b-d) Moderate immunoreactivity CD34-positive cells on Groups B, C, and D (Grade 2).

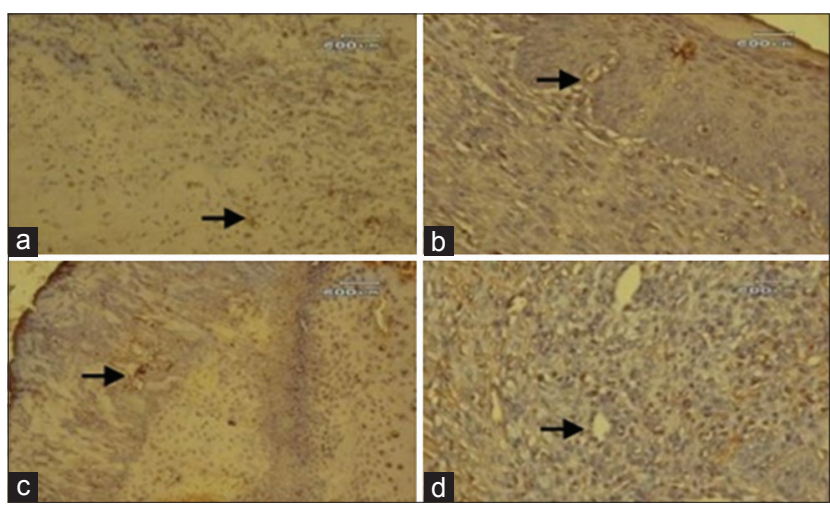

Figure-3: Photomicrograph of wounds skin on day 10 of treatment (streptavidin-biotin 40x). Immunoreactivity CD34 cells each group that marked the brown color (arrow). (a) Minimal immunoreactivity CD34-positive cells on Group A (Grade 1). (b-d) Negative immunoreactivity CD34 cells on Groups B, C, and D (Grade 0).

of CD34 positive cells was found in group B, C, and $\mathrm{D}$ (Grade 2) as seen in Figure-1. In this phase, CD34positive immunoreaction is a sign of angiogenesis or new capillary formation and the migration of endothelial progenitor cells from the vascular.

The results of the day 7 showed that the migration of endothelial progenitor cells and new capillaries more clearly seen. As seen in Figure-2, the minimal immunoreactivity of CD34 positive cells in endothelial cells were observed on group A (Grade 1), but on group $\mathrm{B}, \mathrm{C}$, and $\mathrm{D}$ we found the moderate immunoreactivity of CD34 positive cells (Grade 2). The cream from $10 \%$ and $15 \%$ latex of $J$. curcas and sulfadiazine $0.1 \%$ cream revealed moderate immune reaction to CD34 on days 3 and 7 in mice skin wound healing.

The results show that the number of endothelial progenitor cells in migratory and differentiated tissue decreases with the endothelial formation on day 10. As shown in Figure-3, the minimal immunoreactivity of CD34 positive cells was only found on group A (Grade 1). However, the negative immunoreactivity of CD34 cell was found on group B, C, and D (Grade 0). In this phase, CD34 is a negative immune reaction in
Groups B, C, and D as a sign of the wound healing process.

\section{Discussion}

The simplest interpretation of our finding on day 3 is shown in Figure-1 and day 7 is shown in Figure-2; it was found that the angiogenesis on Groups B, C, and D (Grade 2) is better than the Group A (Grade 1). Guo et al. [7] reported a close correlation between an increase in circulating $\mathrm{CD} 34^{+}$cells in response to traumatic injury and angiogenesis in traumatic brain injury. A significant increase in the number of circulating CD34+ cells detected in traumatic brain injury. Indeed, the high levels of CD34+ were also observed in 7 days after the injury. The results found that angiogenesis involved in inflammation phase (day 3 ) and proliferative phase (day 7). The levels of angiogenesis in wounds often correlate with the inflammatory response, largely because inflammatory cells produce an abundance of proangiogenic mediators [7]. In confirmation of our previous study, we found that the cream from the $10 \%$ and $15 \%$ latex of $J$. curcas revealed moderate immune reaction to $\mathrm{CD} 68$ on wound healing [24]. Macrophages as inflammatory cells secrete vascular endothelial growth factor (VEGF) that induces angiogenesis [30].

Here, we described that the CD34 monoclonal mouse antibody had a strong reaction with antigen on the endothelial progenitor cells and endothelial cells. Clinical and animal studies provide evidence that stem progenitor cells are critical for neovascularization [31]. Angiogenesis is the growth of new blood vessels from existing endothelial cells of the wound's adjacent by mature stromal cells such as fibroblasts [32]. The similar phenomenon described by Ieronimakis et al. [33] who noticed that the fraction of $\mathrm{CD} 34^{+}$cells remains steady during homeostasis and injury regeneration.

In this study, we agree with and support those of Kirby et al. [34] who explained that most hematopoietic stem cells express CD45, and subset of hematopoietic stem cells express CD34. Blood vessels are composed of epithelial tubes with epithelial cells that transport crucial fluid. During lumen formation, endothelial cells in mature blood vessels represented as the first phenotype and second phenotype, and endothelial cells polarization often starts with the delivery through exocytosis, such as CD34 [35].

The effect of $J$. curcas especially on wound healing has been studied using animal models. Many previous reports exist about the efficacy of $J$. curcas on wound healing. Jasmadi et al. [36] evaluated that the ointment from $10 \%$ latex of $J$. curcas has the potential to accelerate the wound healing of burns on the skin of mice. Salim et al. [37] indicated that methanol extract of $J$. curcas leaves was potential in accelerating wound healing in mice. Our previous study indicated that ointment from $10 \%$ latex of $J$. curcas has proven to accelerate the epithelial period [38,39], and remodeling period on wound healing in mice skin [40]. This 
causes that the ointment from $10 \%$ latex of $J$. curcas effective to be used for topical therapy on wound healing in mice skin. The quercetine and routine flavonoids at $J$. curcas can improve the wound healing process on the regulation of VEGF expression for the growth of new blood vessels (angiogenesis) [18]. Angiogenesis involved in the proliferative phase which is a principal step in epithelialization of wound healing [5].

This results study showed that on day 10, CD34 is undetected on Groups B, C, and D (Grade 0). The decrease in the number of migratory and differentiated endothelial progenitor cells was in line with endothelial cells formation [41]. DiPietro [42] stated that after an injury, levels of proangiogenic factors increase, reaching a peak slightly before maximum capillary content occurs, and then subside to nearly undetectable levels.

\section{Conclusion}

We concluded that the cream from $10 \%$ and $15 \%$ latex $J$. curcas has potential as angiogenesis activity in wound healing of mice skin.

\section{Authors' Contributions}

Darmawi and MNS designed the research; UB and CDI performed immunohistochemistry; UB, Darmawi, CDI, and MNS prepared the manuscript. All authors read and approved the final manuscript.

\section{Acknowledgments}

We wish to thank the Directorate of Research and Community Service, the Directorate General of Strengthening Research and Development, Ministry of Research, Technology and Higher Education of Republic Indonesia for funding of the work grant from the Hibah Bersaing with contract number: 129/SP2H/ LT/DRPM/III/2016.

\section{Competing Interests} interests.

The authors declare that they have no competing

\section{References}

1. Prasetyono, T.O.H. (2009) General concept of wound healing, revisited. Med. J. Indones., 18(3): 208-216.

2. Agyare, C., Boakye, Y.D., Bekoe, E.O., Hensel, A., Dapaah, S.O. and Appiah T. (2016) Review: African medicinal plants with wound healing properties. $J$. Ethnopharmacol., 177: 85-100.

3. Velnar, T., Bailey, T. and Smrkolj, V. (2009) The wound healing process: An overview of cellular and molecular mechanism. J. Int. Med. Res., 37: 1528-1542.

4. Guo, S. and DiPietro, L.A. (2010) Factor affecting wound healing. J. Den. Res., 89(3): 219-229.

5. Honnegowda, T.M., Kumar, P., Udupa, E.G., Kumar, S., Kumar, U. and Rao, P. (2015) Role of angiogenesis and angiogenic factors in acute and chronic wound healing. Plast. Aesthet. Res., 2: 243-249.

6. Masir, O., Manjas, M., Putra, A.E. and Agus, S. (2012) Effect of fibroblast filtrate culture fluid (CFF) on wound healing: Experimental study on wistar norvegicus rats. J. Kes. Andal., 1(3): 112-117.

7. Guo, X., Liu, L., Zhang, M., Bergeron, A., Cui, Z., Dong. J. and Zhang, J. (2009) Correlation of CD34+ cells with tissue angiogenesis after traumatic brain injury in a rat model. J. Neurotrauma, 26(8): 1337-1344.

8. Nielsen, J.S. and McNagny, K.M. (2008) Novel function of the CD34 family. J. Cell Sci., 121:3683-3692.

9. Sidney, L.A., Branch, M.J., Dunphy, S.E., Dua, H.S. and Hopkinson, A. (2014) Concise review: Evidence for CD34 as a common marker for diverse progenitors. Stem Cells, 32: $1380-1389$

10. Ruswanti, E.O., Cholil., and Sukmana, B.I. (2014). The effectiveness of papaya leaf ethanol extract (Carica papaya) $100 \%$ on wound healing. Dentino. J. Kedokteran Gigi., 2(2): 162-166.

11. Yuniarti, W.M. and Lukiswanto, B.S. (2017) Effects of herbal ointment containing the leaf extracts of Madeira vine (Anredera cordifolia (Ten.) Steenis) for burn wound healing process on albino rats. Vet. World, 10(7): 808-813.

12. Krishnaiah, D., Devi, T., Bono, A. and Sarbatly, R. (2009) Studies on phytochemical constituents of six Malaysian medicinal plants. J. Med. Plants Res., 3(2): 67-72.

13. Abdelgadir, H.A. and Staden, J.V. (2013) Ethnobotany, ethnopharmacology and toxicity of Jatropha curcas L. (Euphorbiaceae): A review. South Afr. J. Bot., 88: 204-218.

14. Setyaningsih, D., Panji, C. and Perwatasari, D.D. (2014) Study of antioxidant and antimicrobial activity of leaves and twigs extracts and fraction of Jatropha curcas L.and its utilization in personal hygiene products. Agritech, 34(2): 126-137.

15. Nayak, B.S. and Patel, K.N. (2010) Pharmacognostic studies of the Jatropha curcas leaves. Int. J. Pharm. Tech. Res., 2(1): 140-143.

16. Kamal, S., Manmohan, S. and Birendra, S. (2011) A review on chemical and medicobiological applications of Jatropha curcas. Int. Res. J. Pharm., 2(4): 61-66.

17. Prasad, D.M.R., Izam, A. and Khan, M.R. (2012) Jatropha curcas: Plant of medical benefits. J. Med. Plants Res., 6(14): 2691-2699.

18. Esimone, C.O, Nworu, C.S. and Jackson, C.L. (2008) Cutaneous wound healing activity of a herbal ointment containing the leaf extract of Jatropha curcas L. (Euphorbiaceae). Int. J. Appl. Res. Nat. Prod., 1: 1-4.

19. Sharma, A.K., Gangwar, M., Tilak, R., Nath, G., Sinha, A.S.K., Tripathi, Y.B. and Kumar, D. (2012) Comparative in vitro antimicrobial and phytochemical evaluation of methanolic extract of root, stem and leaf of Jatropha curcas Linn. Phcog. J., 4(30): 34-40.

20. Oskoueian, E., Abdullah, N., Saad, W.Z., Omar, A.R., Ahmad, S., Kuan, W.B., Zolkifli, N.A., Hendra, R. and Ho, Y.W. (2011) Antioxidant, anti-inflammatory and anticancer activities of methanolic extracts from Jatropha curcas Linn. J. Med. Plants Res., 5(1): 49-57.

21. Patil, R.N., Patil, R.Y., Ahirwar, B. and Ahirwar, D. (2011) Evaluation of antidiabetic and related actions of some Indian medicinal plants in diabetic rats. Asian Pac. J. Trop. Med., 4(1): 20-23.

22. Sachdeva, K., Garg, P., Singhal, M. and Srivastava, B. (2011) Wound healing potential of extract of Jatropha curcas L. (stem bark) in rats. Phcog. J., 3(25): 67-72.

23. Muntiaha, M.C., Yamlean, P.V.Y. and Lolo, WA. (2014) Test effectivity Jatropha multifida L. to heal wound infection cause by Staphylococcus aureus in rabbit (Orytolagus cuniculus). Pharmacon, 3(3): 294-302.

24. Salim, M.N., Masyitha, D., Harris, A., Balqis, U., Iskandar, C.D., Hambal, M. and Darmawi (2018) Anti-inflammatory activity of Jatropha curcas Linn. latex in cream formulation on CD68 expression in mice skin wound. Vet. World, 11(2): 99-103.

25. Darmawi, D., Balqis, U., Hambal, M., Tiuria, R., Frengki and Priosoeryanto, B.P. (2013) Mucosal mast cell response in jejunum of Ascaridia galli-infected laying hens. Media Peternak., 36(2): 113-119.

26. Balqis, U., Hambal, M., Rinidar, Athaillah, F., Ismail, Azhar, Vanda, H. and Darmawi, D. (2017) Cuticular surface 
damage of Ascaridia galli adult worms treated with Veitchia merrillii betel nuts extract in vitro. Vet. World, 10(7): 732-737.

27. Darmawi, D., Balqis, U., Hambal, M., Tiuria, R., Priosoeryanto, B.P. and Handharyani, E. (2012) The ability of immunoglobulin yolk recognized the antigen in the tissue of Ascaridia galli. Media Peternak., 35(3): 190-195.

28. Yoshida, C.K., Ichimura, T., Kawamura, N., Nakano A., Kasai, M., Sumi, T. and Ishiko, O. (2009) A scoring system for histopathologic and immunohistochemical evaluation of uterine leiomyosarcomas. Oncol. Rep., 22: 725-731.

29. Goel, M.M., Agrawal, D., Natu, S.M. and Goel, A. (2011) Hepsin immunohistochemical expression in prostate cancer in relation to Gleason's grade and serum prostate-specific antigen. Indian J. Pathol. Microbiol., 54(3): 476-481.

30. Nucera, S., Biziato, D. and Palma, M.D. (2011) The interplay between macrophages and angiogenesis in development of tissue injury and regeneration. Int. J. Dev. Biol., 55: 495-503.

31. Thom, S.R., Hampton, M., Troiano, M., Mirza, Z., Malay, D.S., Shannon, S., Jennato, N.B., Donohue, C.M., Hoffstad, O., Woltereck, D., Yang, M., Yu, K., Bhopale, V.M., Kovtun, S. and Margolis, D.J. (2016) Measurements of CD34+/CD45-dim stem cells predict healing of diabetic neuropathic wounds. Diabetes, 65: 486-497.

32. Velazquez, O.C. (2007) Angiogenesis and vasculogenesis: Including the growth of blood vessels and wound healing by stimulation of bone marrow-derived progenitor cells mobilization and homing. J. Vasc. Surg., 45: 39A-47A.

33. Ieronimakis, N., Balasundaram, G., Rainey, S., Srirangam, K., Yablonka-Reuveni, Z. and Reyes, M. (2010) Absence of CD34 on murine skeletal muscle satellite cells marks a reversible state of activation during acute injury. PLoS One, 5(6): e10920.
34. Kirby, G.T.S., Mills, S.T., Cowin, A.J. and Smith, L.S. (2015) Stem cells for cutaneous wound healing. Biomed. Res. Int., Article ID: 285869, 11 Pages.

35. Ribatti, D. and Crivellato, E. (2012) Sprouting angiogenesis, a reappraisal. Dev. Biol., 372: 157-165.

36. Jasmadi, R., Salim, M.N., Harris, A., Aisyah, S., Armansyah, T. and Amiruddin, A. (2016) Effectiveness of Jatropha sap ointment $10 \%$ (Jatropha curcas Linn.) and gentamicin ointment $0.1 \%$ on combustion injury II healing on mice skin (Mus musculus). J. Med. Vet., 10(2): 120-122.

37. Salim, M.N., Darmawi, Balqis, U., Iskandar, C.D. and Masyitha, D. (2016) Wound healing effect of leaf extract of Jatropha curcas Linn in mice. Proc. Ann. Int. Con. (AIC) Syiah Kuala Univ., 6: 181-184.

38. Fauzi, F., Salim, M.N. and Nazaruddin, N. (2017) Effectivity of Jatropha Sap ointment (Jatropha curcas, Linn) on epithelialization phase of incision wound recovery on mice (Mus musculus). Jim. Vet., 1(3): 324-333.

39. Murti, D.A., Salim, M.N. and Sabri, M. (2017) The effectivity excretion of Jatropha salve (Jatropha curcas, L) to epithelization phase of mice (Mus musculus) cutaneous wound healing with masson trichrome stain. Jim. Vet., 1(3): 465-472.

40. Nanda, Y., Salim, M.N. and Iskandar, C.D. (2017) Histopathology of mice (Mus-musculus) skin on remodeling phase of wound healing incision using Jatropha curcas ointment sap. Jim. Vet., 1(4): 780-787.

41. Sabirin, I.P.R., Maskoen, A.M. and Hernowo, B.S. (2013) Role of noni (Morinda citrofolia L.) leaf ethanolic topical application on wound healing examined from CD34 immunoexpression and collagen on wistar rats. J. Ked. Bandung, 45(4): 226-233.

42. DiPietro, L.A. (2016) Angiogenesis and wound repair: When enough is enough. J. Leukoc. Biol., 100(5): 979-984. 